\title{
Perkawinan Lesbian, Gay, Biseksual, dan Transgender dalam Perspektif Hukum Islam dan Hukum Positif
}

\author{
Mulyono \\ Institut Agama Islam Negeri (IAIN) Curup \\ mulyouno999@gmail.com
}

\begin{abstract}
This article aims to conduct an in-depth comparison of LGBT marriages in the perspective of Islamic law and positive Indonesian law. This is a study on normative laws (doctrine) using deductive logic in analyzing primary and secondary legal materials. The results of this study are (1) in the perspective of Islamic laws, same-sex marriage among LGBT is forbidden since it violates the nature and is contrary to maqasid syariah in the sense that it could threaten the essential needs of existence of human beings such as not preserving religion, soul, descendants, mind and honor; (2) in the perspective of positive laws in Indonesia, the state allows merely the marriage between male and female and that it should be in accordance with their religion. Meanwhile, all religions in Indonesia, including Islam, forbid same-sex marriage. Therefore, marriage among LGBT is unlawful and as a result the state does not guarantee their prosperity.
\end{abstract}

Keywords: Marriage LGBT, Islamic Law, Positif Law

\begin{abstract}
Abstrak
Artikel ini bertujuan untuk melakukan perbandingan mendalam tentang perkawinan LGBT dalam perspekif hukum Islam dan hukum positif Indonesia. Penelitian ini merupakan penelitian hukum normatif (doktriner), dengan menggunakan logika deduktif dalam menganalisis bahan hukum primer dan sekunder. Hasil dari kajian ini menunjukkan, dalam perspektif hukum Islam, perkawinan sesama jenis oleh kaum LGBT adalah dilarang karena menyalahi kodrat dan bertentangan dengan maqâshid al-syariah, karena dapat mengancam eksistensi kebutuhan esensial bagi kehidupan manusia, yaitu tidak terpeliharanya agama, jiwa, keturunan, akal, dan kehormatan. Dalam perspektif hukum positif Indonesia, negara hanya membolehkan perkawinan yang dilakukan antara laki-laki dan perempuan, dan pelaksanaannya harus sesuai dengan agamanya masingmasing. Sementara semua agama di Indonesia, termasuk Islam, tidak membolehkan adanya perkawinan sejenis. Jika dilakukan perkawinan sesama jenis oleh kaum LGBT, maka perkawinannya dianggap tidak sah yang berimplikasi kepada tidak diperolehnya jaminan kesejahteraan sosial dari negara bagi kaum LGBT yang melakukan perkawinan.
\end{abstract}

Al-Istinbath : Jurnal Hukum Islam Vol. 4, No. 1, 2019; 101-124

p-issn: 2548-3374; e-issn: 2548-3382; DOI: 10.29240/jhi.v4i1.789

Available online at: http://journal.staincurup.ac.id/index.php/alistinbath 
Kata Kunci: Perkawinan LGBT, Hukum Islam, Hukum Positif

\section{Pendahuluan}

Di Indonesia, isu fenomenal perkawinan LGBT semakin mencuat ke permukaan danmenjadi perbincangan publik sejak tahun 1981, bahkan pelaksanaan perkawinan LGBT tidak lagi dilakukan dengan sembunyi-sembunyi, akan tetapi sudah tidak lagi menjadi hal yang tabu untuk dipertontonkan kepada publik sebagai bentuk usaha mendapatkan pengakuan dan tempat di masyarakat.Pada tanggal 6 Juli 1981, telah dilaksanakan pernikahan pasangan lesbian antara Jossie dan Bonie di sebuah Cafee di Jakarta. ${ }^{1}$ Pada tahun 2008 terjadi pernikahan pasangan gay di Yogyakarta, antara Wim dan Philip. ${ }^{2}$ Kemudian fenomena perkawinan sejenis ramai diperbincangkan kembali setelah tersebarnya dua berita pernikahan dua pasang pria yang menghebohkan media sosial pada tahun 2015 lalu, yakni antara pernikahan antara warga Indonesia yang bernama Tiko Mulya dan warga Negara asing yang bernama Joe Tully yang digelar di Bali dengan upacara adat Hindu. ${ }^{3}$ Pada bulan Juli 2017 telah terjadi perkawinan LGBT antara Fadholi (21) dan Ayu Puji Astuti (23) warga Kecamatan Ajung Jember, yang sebenarnya keduanya adalah berjenis laki- laki. Kasus ini menjadi heboh karena pernikahan tersebut dilakukan secara resmi di hadapan pejabat KUA dan memiliki legalitas formal. ${ }^{4}$ Baru-baru ini pada tahun 2019 Sepasang gay diamankan warga sedang bercumbu di lapangan sepakbola Sari Bulan, Sawah Padang Aur Kuning, Payakumbuh Sumatera Barat. Satu di antaranya anak-anak. "Ada warga yang curiga dengan gerak gerik mereka, karena terlihat mencari tempat sepi dan agak gelap di sekitar lapangan, "kata Devitra kepada detikcom, Rabu (9/1/2019).

Fenomena perkawinan LGBT tersebut menimbulkan pro dan kontra di kalangan masyarakat, baik pihak yang menentang maupun mereka yang pro kelompok LGBT. Mereka berupaya menghadirkan berbagai argumentasi dari beberapa sudut pandang. Dalam konteks masyarakat beragama seperti di Indonesia, mayoritas publik menggunakan sudut pandang agama dengan merujuk pada teks-teks keagamaan yang mereka yakini. Berdasar pada

${ }^{1}$ M.F. Mukthi, Bukan Cinta Biasa, https://historia.id/budaya/articles/bukan-cintabiasa-DrbGD, diaksespada 17 Maret 2019

2Jalan Berliku Kaum Homo Menuju Pelaminan, GATRA, Edisi 46 Beredar Jumat 26 September 2003, http://arsip.gatra.com/2003-09-28/artikel.php?id=31335, diakses pada 17 Maret 2019

${ }^{3}$ https://www.jpnn.com/kemenpan/news/inilah-11-pernikahan-yang-bikin-heboh, diakses pada 17 Maret 2019

${ }^{4} \mathrm{http}: / /$ suaraindonesia- news.com/pasangan- diduga- sesama- jenis- berhasil- menikahini- jawabankemenag-jember/, diakses pada 17 Maret 2019

${ }^{5}$ https://news.detik.com/berita/d-4377678/miris-anak-di-sumbar-tepergok-mesumdengan-sesama-laki-laki?_ga=2.101912833.1277451655.1552961077-554812675.1552961077, diakses, 19 Maret 2019 
argumentasi transendental (Alquran dan hadis) dan pendapat para ulama fikih dengan merujuk kisah Nabi Luth, serta maqâshid al-syarı̀ah, pada umumnya masyarakat muslim menolak perkawinan sesama jenis.

Sedangkan masyarakat yang pro perkawinan LGBT, baik dari kalangan akademisi maupun pegiat feminisme,bergerak dari ranah politik hingga teologi. Di bidang politik, usaha ini diwujudkan dengan mengupayakan legalisasi Rancangan Undang-Undang Keadilan dan Kesetaraan Gender (RUU KKG) yang memberikan celah bagi pernikahan sesama jenis. ${ }^{6}$ Adapun di bidang teologis, kampanye dilakukan dengan membongkar bangunan keagamaan yang selama ini menjadikan heteroseksual sebagai satu-satunya pilihan seksualitas manusia.

Dukungan terhadap kebolehan hubungan LGBT di Indonesia datang dari intelektual Muslim Indonesia, diantaranya adalah Musdah Mulia dan Husein Muhammad. Dalam pandangan mereka, Alquran tidak melarang secara eksplisit terhadap homoseksual, tetapi yang dilarang adalah perilaku seksual dalam bentuk sodomi atau liwâth. Masyarakat umumnya mengira bahwa setiap pelaku homo pasti melakukan sodomi untuk pemuasan nafsu biologisnya, padahal belum tentu demikian. Sodomi bahkan dilakukan pula oleh orang-orang heteroseksual. ${ }^{8}$

Pembolehan perkawinan sejenis (LGBT) menurut Musdah dikarenakan beberapa alasan yakni: pertama, tidak ada perbedaan antara laki-laki dan perempuan. Manusia, baik laki-laki maupun perempuan, adalah sederajat, tanpa memandang etnis, kekayaan, status sosial, ataupun orientasi seksual. Dalam pandangan Tuhan, manusia dihargai hanya berdasarkan ketaatannya. Kedua, intisari dari ajaran Islam adalah memanusiakan manusia dan menghormati kedaulatannya. Homo seksualitas adalah pemberian Tuhan yang bersifat alami dan diciptakan oleh Tuhan (takdir), oleh karena itu diperbolehkan dalam agama Islam. Ketiga, dalam teks-teks suci yang dilarang lebih tertuju kepada perilaku seksualnya, bukan pada orientasi seksualnya. Manusia menjadi heteroseksual atau homoseksual itu bersifat kodrati, sementara perilaku seksual itu bersifat konstruksi manusia. Sehingga perlu ada pendefinisian ulang tentang konsep perkawinan, di mana pasangan perkawinan tidak harus berjenis kelamin yang berbeda, tapi juga boleh sejenis.'

Penelitian ini merupakan penelitian hukum normatif (doktriner), yaitu

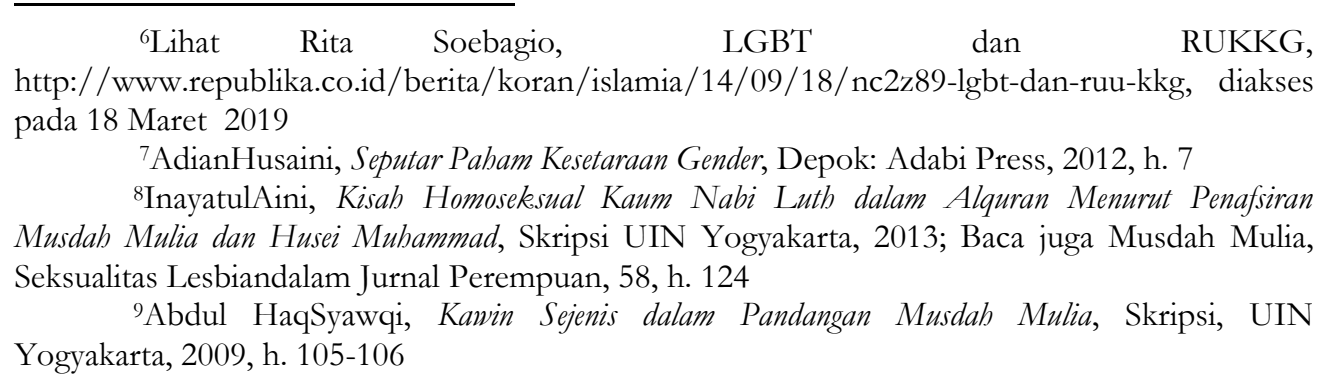


penelitian yang mengacu kepada norma-norma hukum yang terdapat dalam peraturan perundang-undangan dan norma-norma yang hidup dan berkembang dalam masyarakat. ${ }^{10}$ Penelitian ini merupakan penelitian kepustakaan yang menggantungkan pada data sekunder, yaitu informasi yang terdapat dalam dokumen-dokumen yang terkait dengan perkawinan LGBT baik dalam hukum Islam maupun dalamperaturanperundang-undangan Indonesia.

Metode yang sesuai untuk menganalisis isi dokumen yang mengandung pesan-pesan komunikasi tertentu adalah metode analisis isi (content analysis). ${ }^{11}$ Logika yang digunakan dalam menganalisis bahan hukum adalah deduktif, dengan maksud untuk mengetahui tentang detil-detil pemahaman yang ada dalam berbagai teks. ${ }^{12}$ Dalam penelitian ini, peneliti mencatatkan ayat-ayat Alquran, hadis-hadis, pendapat ulama dalam kitab-kitab fikih terkait perkawinan dan LGBT, Kompilasi Hukum Islam tentang perkawinan, dan Undang-Undang tentang Perkawinan, kemudian menganalisis kandungan hukum tentang perkawinan LGBT yang ada dalam bahan-bahan hukum tersebut.

Berdasarkan hal di atas, menarik rasanya mendalami kajian tentang bagaimana sebenarnya perkawinan LGBT dalam perspekif hukum Islam dan hukum positif Indonesia.

\section{Pembahasan}

Secara psikologi dan fikih, istilah LGBT jika dikaitkan dengan orientasi dan anatomi seksual maka dapat diciri-cirikansebagai berikut:

\begin{tabular}{|l|l|c|c|}
\hline \multirow{2}{*}{ Ragam Seksualitas } & \multicolumn{2}{|c|}{ Ciri-ciri } & \multicolumn{2}{|c|}{ Istilah } \\
\cline { 3 - 4 } & & Psikologi/Medis & Fikih \\
\hline Homoseksual & $\begin{array}{l}\text { Orientasi seksual dan perilaku } \\
\text { seksual sesama jenis, tapi } \\
\text { tidak merasa perlu } \\
\text { berpenampilan dengan } \\
\text { memakai pakaian lawan jenis }\end{array}$ & Lesbian & Sihâq \\
\hline Biseksual & $\begin{array}{l}\text { Orientasi seksual Kepada dua } \\
\text { jenis kelamin sekaligus }\end{array}$ & Biseksual & $\begin{array}{c}\text { Liwâth } \\
\text { jinns al- }\end{array}$ \\
\hline
\end{tabular}

${ }^{10}$ Zainuddin Ali, Metode Penelitian Hukum, Jakarta: Sinar Grafika, 2013, h. 105

${ }^{11}$ Earl Babbie, The Practice of Social Research, Wadsworth Publishing Co. Calofornia, 1986, h. 266

${ }^{12}$ Sutrisno Hadi, Metodologi Research, Cet. Ke-2, Yogyakarta: Andi Offset, 1989, h. 142 


\begin{tabular}{|l|l|l|}
\hline \multirow{5}{*}{ Transgender } & $\begin{array}{l}\text { Anatomi seksual, perilaku } \\
\text { menyerupai jenis penampilan } \\
\text { lawan jenis merasa dan } \\
\text { menjalani hidup sebagaiTransgender/ } \\
\text { perempuan dalam tubuh laki-Waria } \\
\text { laki atau sebaliknya, tidak } \\
\text { selalu berimplikasi kepada } \\
\text { perilaku seksual sesama jenis }\end{array}$ & Mukhannats \\
\hline Hermafrodit & $\begin{array}{l}\text { Anatomi seksual, mengalami } \\
\text { kerancuan alat kelamin luar, } \\
\text { tanpa gangguan orientasi } \\
\text { seksual dan gender }\end{array}$ & Mutarajjilât \\
\hline
\end{tabular}

\section{LGBT dalam Literatur Islam}

Dalam literatur Islam tidak dikenal istilah LGBT. Namun istilah yang umum dipergunakan untuk orientasi dan perilaku homoseksual adalah liwâth (اللواط),berasal dari kata "yang termasuk kata a'jamiy (asing/non Arab).Kata liwâth lebih banyak diartikan dengan melakukan perbuatan seperti perbuatan kaum Nabi Luth. ${ }^{13}$ Menurut al-Nawawi, dinamakan liwâth karena yang pertama kali melakukannya adalah kaum Nabi Luth. ${ }^{14}$ Al-Mawardi mengartikan kata liwâth dengan persetubuhan antara laki-laki dengan laki-laki. Dengan demikian, dalam konteks bahasa Indonesia,istilahliwâth merupakan bentuk homoseksual yang secara spesifik dapat dipadankandengan istilah gay, yakni bentuk gaya hubungan antara laki-laki dengan laki-laki.

Selain istilah liwâth, dalam literatur Islam juga dikenal istilah sihâq (سحاق). Istilah ini digunakan dalam Bahasa Arab untuk menunjuk makna lesbian/ lesbianisme. Secara terminologi, sihâq berarti perbuatan perempuan terhadap perempuan lainnya sebagaimana yang ia lakukan bersama laki-laki. ${ }^{15}$ Sayid Sabiq memberikan definisi kata sihâq dengan hubungan cinta birahi antara sesama wanita dengan image dua orang wanita saling menggesek-gesekkan anggota tubuh (farji) nya antara satu dengan yang lainnya, hingga keduanya merasakan kelezatan dalam berhubungan tersebut. ${ }^{16}$

Homoseksual(lesbiandangay)biasadipahamidalampengertianorientasiseks

\footnotetext{
${ }^{13}$ Muhammad bin Abi al-Fath al-Ba'li, Al-Mutthâli' 'alâAlfâz̆b al-Muqni', Juddah: Maktabah al-Sawadi, 2003), h. 360 h. 324

${ }^{14}$ Yahya bin Syaraf al-Nawâwi, TahrìrAlfâz̧̧ al-Tanbîh, (Damaskus: Dar al-Qalam, 1988),

${ }^{15}$ Wizarah al-Awfaq wa Syu'un al-Islami, (Mausû'ah al-Fikihiyah al-Kuwaitiyyah, t.tp: Dar as-Safwah, 1427H), Vol. XXIV, h. 217

${ }^{16}$ Sayid Sabiq, Fikih al-Sunnah, (Beirut: Dar al-Fikr, 1980), Juz 4, h. 51
} 
ual dan perilaku seksual. ${ }^{17}$ Sebagian ulama' berpendapat bahwa orientasi seksual adalah pemberian Allah yang bersifat kodrati, given, anugerah, dan di luar kemampuan manusia untuk mengubahnya.Meskipun demikian, orientasi seksual mungkin juga dipengaruhi oleh faktor lingkungan-sosial. Jika orientasi seksual itu bersifat kodrati, maka tidak seharusnya seseorang yang tertarik sesama jenis di wilayah orientasi seksual(kecenderungan dalam hati/pikiran) yang dianggap "menyimpang" ini, diadili sebagai sesuatu yang haram. Inilah yang dalam istilah ushul fiqih disebut dengan at-taklif bi al-mubâl. Karena setiap manusia sulit melepaskan diri dari ketertarikan berbuat maksiat yang tiba-tiba menyelinap dalam kalbunya. Oleh sebab itu, al-nafs, alhâm, dan al-'az̧m untuk melakukan maksiat belum ditulis sebagai keburukan (sayyi'ât) sebelum lahir menjadi "perilaku maksiat" yang sesungguhnya. ${ }^{18}$

Adapun perilaku seksual tidaklah bersifat kodrati, tetapi karena dipengaruhi oleh faktor lingkungan dan dapat dipelajari. Dengan demikian, jika seorang lesbian atau gay memperturutkan orientasi seksualnya dengan melakukan hubungan seksual sesama jenis, maka ia berdosa dan dikenai hukuman.

Istilah biseksual dalam fikih ditujukan bagi orang yang tertarik kepada dua jenis seks sekaligus (tsunaiyal-jins). Sama halnya dengan lesbian dan gay, ketika seorang biseksual tertarik pada sesama jenis hanya di wilayah orientasi seksual, maka tidaklah berdosa. Tetapi jika ia mewujudkannya dalam perilaku seksual dengan sesama jenis maka ia dihukumi seperti liwâth atau sihâq. Dalam konteks Indonesia, mukbannats dapat dipadankan dengan transgender, yang secara umum dimasyarakat disebut dengan waria, banci atau wadam. Dalam literatur fikih, istilah ini ditujukan kepada seorang laki-laki yang mengalami disfungsi ereksi (la yaqûmuzabbubu). ${ }^{19}$ Disfungsinya ereksi bagi mukhannats dikategorikan termasuk ghairi uli al-irbat min al-rijal, yakni seorang laki-laki yang tidak memiliki hajat (orientasi seks) terhadap perempuan. ${ }^{20}$ Sementara Ibnu Katsir menafsirkan ghairi ulì al-irbat min al- rijâl sebagai seorang yang tidak berharap membangun keluarga dengan perempuan dan tidak tertarik secara

${ }^{17}$ Orientasi seksual atau kecenderungan seksual adalah pola ketertarikan seksual, romantis, atau emosional (atau kombinasi dari keseluruhan) kepada orang-orang dari lawan jenis atau gender, jenis kelamin yang sama atau gender, atau untuk kedua jenis kelamin atau lebih dari satu gender. Orientasi seksual secara garis besar dapat dibedakan menjadi tiga, yaitu ekspresi seksual dengan pasangan berlainan jenis (heteroseksual), sesama jenis (homoseksual), atau kedua jenis (biseksual). Lihat https://id.m.wikipedia.org

${ }^{18}$ Imam Nakhe'i, LGBT Perspektif Islam, Jurnal Lisan Al-Hal, Volume 4, No. 2, Desember 2012, h. 365

${ }^{19}$ Pendapat ini dikemukakan oleh al-Firyani, Ibnu Jarir, Imam Muslim, Abu Dawud, alNasa'i, al-Baihaqi, abd.Rozaq, al-Kalabi, Sa'id bin Jubair, al-Syu'bi, dan MardawihdalamAlSuyûthi, al-Durru al-Mantsûrfî al-Tafûir al-Ma'tsûr, Beirut: Dar al-Kutub al-Ilmiyah, t.th, Jilid V, h. $7 \mathrm{w} 8-79$

${ }^{20}$ Al-Suyuthi, al-Durru al-Mantsìr, Jilid I, h. 292 
seksual dengannya. Ia sependapat dengan Ibnu'Abbas, Mujahid dan 'Ikrimah, bahwa ghairi ulì al-irbat min al-rijâl dikategorikan sebagai seorang mu'tawiyah, abillah dan mukhannats. ${ }^{21}$

Al-Nawawi ${ }^{22}$ membagi mukhannats menjadi dua kategori, yakni mukhannatsminkhalqin(kodrati/genetik) dan mukhannatsbitakallufin (bukan kodrati tetapi dibuat-buat). Mukhannatsminkhalqin ditujukan pada laki-laki yang secara genetik memiliki gaya bicara, cara berjalan, karakter, dan perilaku seperti perempuan. Pada kategori ini ulama berpendapat bahwa seseorang dengan kriteria seperti ini tidak dicela, tidak berdosa, serta tidak dilaknat.Sementara istilah mukhannatsbitakallufin itu ditujukan pada seseorang yang secara fitrah adalah laki-laki, tetapi karena pengaruh lingkungan dia berusaha mengimitasi perempuan.Kategori ini yang disebut mendapat laknat atas perilakunya menyerupai lawan jenis, karena sebenarnya secara jasmani dan rohani jelas-jelas sebagai laki-laki.

Antonim dari kata mukhannats adalah mutarajilatat, yaitu perempuan yang berperilaku seperti laki-laki. ${ }^{23}$ Menurut Ibnu Baththal,Rasulullah saw. Melaknatmereka bukan karena memang adanya sifat perempuan atau laki-laki dalam dirinya yang merupakan ciptaan Allah.Laknat itu disebabkan oleh kaum laki-laki yang memperturutkan kecenderungan itu dan berdandan seperti kaum perempuan, dan laknat ini juga berlaku bagi perempuan tulen yang sengaja menyerupai laki-laki. ${ }^{24}$

Jadi, istilah mukhannats dan mutarajïlât tidak terkait dengan orientasi seksual terhadap sesama jenis, melainkan merupakan anatomi seksual, yakni terkait dengan perilaku menyerupai penampilan lawan jenis, maka ia lebih tepat diartikan effeminate, bukan homosexual. Secara material, anatomi seksual tidak selalu berimplikasi kepada perilaku seksual yang dilarang.

Dalam kitab fikih, istilah mukhannats berbeda dengan Khuntsâ (hermafrodit atau ambiguous genetalia). Khuntsâ adalah atribut yang diberikan kepada seseorang yang tidak jelas dqukûrah dan unutsah-nya. Secara material, Khuntsâ merupakan anatomi seksual yang bersifat kodrati (given), tanpa gangguan orientasi seksual dan gender. Menurut pendapat fuqaha', Khuntsâ memiliki dua arti, pertama adalah seseorang yang memiliki dua jenis kelamin seks laki-laki dan perempuan. Kedua adalah seorang yang tidak memiliki kelamin sama sekali. Jika

${ }^{21}$ Ismail IbnKatsir, , Pinang:SulaimanShur'iy, t.th, h. 285

${ }^{22} \mathrm{Abu}$ ZakariyaYahyaIbn Syaraf al-Nawawi, SyarhShabih Muslim, Jilid XIII, t.tp: Dar alKhair, 1998, h. 336-337

${ }^{23}$ istilah mukhannats dan mutarajijlat dijumpai dalam sebuah hadisRasulullah saw. yang diriwayatkan Ibnu Abbas dan Bukhari, Kitab al-Libas, hadis nomor 5886, diakses dari www.hadithportal.com

${ }^{24} \mathrm{Abu}$ al-Hasan Ali bin Khalaf bin Abdil Malik bin Baththal al-Bakri al-Qurtubi, Syarbu Sabih al-Bukhâri li Ibni al-Baththâl, Riyad: Maktabah al-Rusyd, 2003, Vol. IX, h. 141-142 
terdapat seorang yang memiliki kelamin ganda atau tidak memiliki jenis kelamin sama sekali, maka upaya untuk mempertegas salah satu jenis kelaminnya wajib dilakukan. Jika upaya memastikan salah salah satu jenis kelaminnya gagal, maka khuntsâsemacam itu disebut dengan khuntsâmusykil (Khuntsâ yang jenis kelaminnya sulit ditentukan), yang ketentuan hukumnya jauh lebih rumit dari khuntsâ biasa. Di antara ketentuan hukum khusus yang ditimpakan terhadap khuntsâmusykil adalah bahwa mereka tidak boleh menikah. Sebab jika ia menikahi perempuan, maka bisa jadi ia perempuandan begitu pula sebaliknya. Khuntsâ relatif direspon positif dalam teks-teks kitab turâts ketimbang mukhannats karena Khuntsâ bersifat given (takdir dari Tuhan).

\section{Perkawinan LGBT Perspektif Hukum Islam}

Di dalam teks keagamaan tidak ditemukan dalil secara eksplisit yang menjelaskan ketentuan hukum perkawinan LGBT. Meski demikian, hal ini dapat ditelusuri dari dalil transendental (ayat dan hadis), kodifikasi hukum (fikih), maqâshid al-syari'ah, dan Kompilasi Hukum Islam (KHI), yang secara substantif dapat menjelaskan mengenai hukum perkawinan sesama jenis yang dilakukan oleh kaum homoseksual.

\section{Dalil Transendental tentang Perkawinan LGBT}

Alquran menjelaskan bahwa Allah telah menciptakan segala sesuatu di dunia ini berpasang-pasangan dan secara tegas menyebut laki-laki (dzakar)dan perempuan (untsâ) sebagai jenis kelamin manusia, sebagaimana yang termaktub dalam ayat Al- Qur'an berikut: QS. Al-Dzariyat: 49, QS. Al-Syura: 11, dan QS.Al-Qiyamah: 39.

Perkawinan merupakan institusi yang melegalkan hubungan hukum antara seorang laki-laki dengan seorang perempuan. Hal ini didasarkan pada teks Alquran QS. Al-Nisa': 3 dan QS. Al-Baqarah: 223. Pada ayat tersebut, istri digambarkan sebagai "ladang-ladang". Hal ini memberikan petunjuk bahwa pasangan nikah laki-laki haruslah insan yang mampu berproduksi, yakni perempuan. Hal ini juga menunjukkan bahwa perkawinan bukan hanya dimaksudkan sebagai rekreasi melainkan juga prokreasi. Senada dengan ayat tersebut, puluhan ayat lain yang juga menegaskan secara jelas (qhat'iy al-dalalah) bahwa pasangan menikah laki-laki adalah perempuan dan pasangan menikah perempuan adalah laki-laki. ${ }^{25}$ Bahkan di dalam QS.Al-Syu'ara' ayat 166 diyatakan bahwa relasi seperti ini adalah telah menjadi "ketentuan penciptaan" Allah dan ketentuan hukum yang mujma' 'alaih. Kemudian Alquran mengisahkan proses penciptaan manusia, yakni berasal dari nuthfah amsâj yang merupakan percampuran antara benih laki-laki dan perempuan dalam QS. Al-Mukminun: 12-14.

${ }^{25}$ Imam Nakhe'i, Jurnal Lisan Al-Hal, h. 366 
Tujuan perkawinan bagi manusia adalah untuk mewujudkan kehidupan rumah tangga yang sakinah, mawaddah dan rahmah (tenteram, cinta dan kasih sayang), ${ }^{26}$ sebagaimana yang tercermin dalam teks QS. Al-Rum: 21 . Kata litaskuni ilaihâ pada ayat tersebut menunjuk pada tujuan pertama perkawinan, yakni sakinah yang berarti tenang, tenteram, tetap, dan tidak ada rasa takut. Sehingga perkawinan adalah pertemuan antara laki-laki dan perempuan, yang kemudian menjadikan (beralih) kerisauan antara keduanya menjadi ketenteraman atau sakinah. Dengan demikian, perkawinan dimaksudkan sebagai wahana atau tempat orang-orang yang ada di dalamnya terlindungi dan dapat menjalani hidup dengan penuh ketenangan, kedamaian, dan keamanan. ${ }^{27}$

Tujuan perkawinan selanjutnya dalam ayat di atas adalah mawaddah. Quraish Shihab mengartikan kata mawaddah sebagai rasa cinta yang tergambar dalam hubungan laki-laki dan perempuan yang terjalin dalam sebuah perkawinan, yang disertai dengan penuh keikhlasan dalam menerima keburukan dan kekurangan orang yang dicintai. Sedangkan rahmah diartikan dengan perasaan saling simpati, menghormati, menghargai antara satu dengan yang lainnya, saling mengagumi, memiliki kebanggaan pada pasangannya.Sebagaimana sakinah, mawaddah dan rahmah hanya dapat diwujudkan oleh pasangan lain jenis, laki-laki dan perempuan, melalui institusi perkawinan. ${ }^{28} \mathrm{~J}$ ika perkawinan itu dilakukan sesama jenis, maka tujuan perkawinan untuk mencapai sakinah, mawaddah dan rahmah sebagaimana tersebut di atas tidak dapat tercapai, karena perkawinan semacam ini tidak akan menghasilkan keturunan.

Petunjuk lainnya terhadap larangan hubungan sesama jenis adalah adanya perintah menjaga kemaluan serta menyalurkan kebutuhan biologis hanya dengan cara yang benar, antara lain: Q.S. Al-Nur: 30-31, Q.S. Al-Mukminun: 56, dan Q.S. Al-Ma'arij: 29-30.

Ajaran Islam memerintahkan agar laki-laki mengawini perempuan, dan melarang laki-laki mengawini laki-laki atau perempuan mengawini perempuan. Terdapat beberapa teks Alquran tentang kisah perilaku homoseksual kaum Nabi Luth yang dapat dijadikan landasan hukum tentang larangan perkawinan LGBT, yaitu: Q.S. Al-A'raf: 80-81, Q.S. Al-Naml: 55, Q.S. Huud: 78-79, Q.S. AsySyu'ara':165-168, Q.S. An-Naml: 54-55, Q.S. Al-Anbiya': 74, Q.S. Al-Ankabut: 28-29, Q.S. Al-Hijr: 67-74, dan Q.S.Al-Qamar: 37.

Dalam ayat-ayat tersebut, Alquran menyebut aktivitas seksual kaum Luth dengan tiga ungkapan- al-fâkhisatu, as-sayyiatu, dan al-khabûtsâtu- yang berakar

${ }^{26} \mathrm{Ahmad}$ Rofiq, Hukum Perdata Islam di Indonesia, Edisi Revisi, Jakarta: Raja Grafindo Persada, 2013, h. 48-49

${ }^{27}$ M. QuraishShihab, Membumikan Alquran: Fungsi dan Peran Wabyu dalam Kebidupan Masyarakat, Bandung:Mizan, 2000, h. 135

${ }^{28}$ M. QuraishShihab, Pengantin Alquran: Kalung Permata Buat Anak-Anakku, Jakarta: Lentera Hati, 2010, h. 88 
pada satu arti yaitu sesuatu yang keji, kotor, menjijikkan, dan bertentangan dengan kodrat dan tabiat manusia.Atas aktivitas seksual itu Allah juga menghukum mereka dengan beberapa jenis hukuman, yaitu suara menggelegar (al-shaihah), hujan batu, dan terbaliknya bumi yang mereka pijak.Alasan ini pula yang digunakan oleh ulama' dalam mengharamkan aktivitas seksual komunitas LGBT. Larangan disertai ancaman yang mengerikan ini menegaskan bahwa alnahyu(larangan) menikahi laki-laki dalam konteks ini adalah li al-tahrìm.

Sama halnya dengan Alquran, dalam hadis-hadis Nabi saw. juga tidak ditemukan ketentuan hukum yang secara eksplisit menjelaskan tentang perkawinan LGBT. Namun, terdapat beberapa hadis yang menjelaskan larangan berbuat homoseksual yang disertai dengan sanksi hukum bagi pelakunya. Rosulallah SAW bersabda;

"Dari Abd al-Rahman ibn Sa'id Al-Khudri dari ayahnya, babwasanya Rasulullah saw. bersabda: "tidak boleh lelaki melibat aurat lelaki, dan tidak boleh wanita melihat aurat wanita, tidak boleb lelaki bersentuhan kulit dengan lelaki dalam satu busana, dan tidak boleh wanita bersentuhan kulit dengan lelaki dalam satu busana." (HR. Muslim)

Hadis yang menjelaskan sanksi hukum atas perbuatan liwâth (homoseksual) adalah beragam. Ada hadis yang menyamakan liwâth dengan zina:

"Dari Abu Musa, ia berkata: Rasulullah saw. bersabda: Apabila lelaki menggauli lelaki maka keduanya berzina. Dan apabila wanita menggauli wanita maka keduanya berzina." (HR. Al-Baihaqi)

Hadis di atas menunjukkan bahwa perbuatan homoseksual (liwâthatausihâq) dihukumi sebagai zina. Karena disamakan dengan zina, maka sanksi bagi pelaku liwâth atau sihâq juga sama dengan sanksi zina, yakni hadd. Bahkan dalam hadis yang lain dijelaskan bahwa hukuman bagi pelaku liwâth atau sihâq adalah dibunuh, sebagaimana diungkapkan dalam hadis berikut:

"Telah menceritakan kepada kami Abdul Aziz bin Muhammad dari Amru bin Abu Amru dari Ikrimah dari Ibnu Abbas, ia berkata: Rasulullah saw. bersabda: Siapapun yang kalian dapati sedang melakukan seperti apa yang pernah dilakukan kaum Nabi Luth, maka bunublabfa'ilnya dan sekaligus maf 'ul (obyek) nya." (HR. AbiDawud). ${ }^{29}$

Hadis berikut menyatakan bahwa pelaku homoseksual sebagaimana yang dipraktekkan kaum Luthakan dilaknat oleh Allah:

"Dari Ibn Abbas babwa Rasulullah saw. bersabda:Allabmelaknat orang yang melakukan perbuatan kaum Luth sebanyak tiga kali."

Laknat terhadap seseorang yang melakukan perbuatan hubungan

${ }^{29} \mathrm{Abu}$ Dawud Sulaiman bin Al-Asy-ats, SunanAbiDawud, Cet. 1, Dimasyq: Dar alRisalah al-Alamiyah, 2009, h. 38 
homoseksual itu adalah indikasi yang menunjukkan keharaman perbuatan tersebut. Bagi yang melanggar norma ini akan menerima konsekuensi sanksi yang sangat berat.

Disamping melarang hubungan homoseksual, Islam juga melarang manusia berperilaku menyerupai lawan jenisnya sebagaimana yang dilakukan kaum transgender (mukhannnats). Hadis Nabi saw. yang menjelaskan hal ini adalah:

Dari IbnAbbasr.a. berkata, Rasulullah s.a.w. melaknat seorang laki-laki yang menyerupai perempuan dan seseorang perempuanyang menyerupai laki-laki.Diikuti oleh 'AmrdiceritakandariSyu'bah.'Diriwayatkan oleh al-Bukhari.

Al-Asqalani memahami kata al-mutasyabbihìn min al-rijâl bi al-nisâ' waal- mutasyabbihât min al-nisâ' bi al-rijal dalam hadis tersebut sebagai laki-laki yang menyerupai perempuan, dan perempuan yang menyerupai laki-laki, baik dalam berpakaian, perhiasan, perkataan dan perbuatan. Meskipun menurutnya pula, dalam hal tata cara berpakaian dan perhiasan ini terdapat perbedaan di setiap daerah terkait dengan perbedaan sosio-kulturnya. ${ }^{30}$

Berdasarkan paparan hadis di atas dapat dipahami bahwa menyerupai lawan jenis dan melakukan hubungan homo seksual adalah dilarang oleh Islam karena menyalahi kodrat. Perilaku seksual yang dibenarkan Islam adalah bersifat heteroseksual. Bagi kaum LGBT yang secara nyata memiliki jenis kelamin yang sama kemudian melakukan perkawinan berarti telah melanggar norma agama dan akan menerima konsekuensi sanksi yang sangat berat.

\section{Perspektif Maqâshid al-syatî'ah tentang Perkawinan LGBT}

Kehadiran hukum Allah yang dijadikan pedoman hidup umat manusia memiliki tujuan utama (maqâshid al-syari'ah), yakni mewujudkan kemaslahatan bagi kehidupan manusia dengan mendatangkan kesejahteraan dan menjauhkan bahaya dalam kehidupan manusia.Nilai kemaslahatan dapat diartikan sebagai suatu yang baik dan dapat diterima oleh akal sehat, ${ }^{31}$ artinya bahwa akal itu dapat mengetahui dengan jelas argumentasi mengapa suatu hukum ditetapkan.

Menurut al-Syatibi, ada tiga tingkatan maqâshid al-syari'ah, yakni dlarûriyât, bâjiyat dan tabsiniyyat. ${ }^{32}$ Yang dimaksud dengan memelihara kelompok dlarûriyat adalah memelihara kebutuhan-kebutuhan yang bersifat esensial bagi kehidupan manusia, kebutuhan yang esensial itu adalah memelihara agama, jiwa, keturunan, akal, danharta, dalam batas jangan sampai eksistensi kelima pokok tersebut terancam. Sementara menurut JasserAuda, kebutuhan yang esensial itu ada enam

\footnotetext{
${ }^{30}$ Ahmad ibn Ali ibn Hajar al-'Asqalani, Fath al-Bâri, Beirut: al-Risalah al-'Alamiyyah, 2013, h.409-410

${ }^{31}$ Amir Syarifuddin, Ushûlal-Fikih, Jilid II, Jakarta: Logos, 1997, h. 207

${ }^{32} \mathrm{Al}-$ Syatibi, al-Muwâfaqat fi Ushûl al-Syarîah, Beirut: Dar al-Ma'rifah, 1996, Juz IV, h. 8
} 
(al-dlarûriyat al-sittah). ${ }^{33}$ Selain memelihara kelima kebutuhan yang bersifat esensial tersebut, Jasser Auda menambahkan pentingnya memelihara kehormatan. Jika kebutuhan-kebutuhan tersebut tidak terpenuhi maka akan berakibat terancamnya eksistensi keenam pokok tersebut.

Atas dasar kemaslahatan, Islam telah mengatur perkawinan. Dalam perspektif Islam, perkawinan merupakan ajaran agama yang bernilai ibadah yang diperintahkan Allah dan Rasul-Nya kepada setiap muslim yang telah mampu menjalankannya agar dapat memelihara agama, kehormatan diri, pandangan, mengarahkan kebutuhan biologis terhadap lawan jenis secara benar dan untuk menata kehidupan mereka sebaik-baiknya sehingga mereka memperoleh kebahagiaan dunia dan akhirat. Dengan adanya perkawinan yang sah antara lakilaki dan perempuan maka eksistensi ajaran agama dapat terjaga (bif̧̌̉ al-din).

Tujuan terpenting lainnya dari sebuah perkawinan adalah untuk memperoleh keturunan dan melestarikan kehidupan manusia (bif̌̌b al-nash). Melalui perkawinan yang sah akan muncul keturunan yang sah dan diakui di hadapan hukum. Munculnya keturunan baru manusia hanya dapat diwujudkan jika perkawinan dilakukan oleh pasangan laki-laki dan perempuan, sebagaimana firman Allah dalam Q.S. Al-Hujurat ayat 13.

Pada hakikatnya Islam selalu menjunjung harkat dan martabat manusia dengan penekanan perintah untuk selalu menjaga prinsip-prinsip kebaikan (maslahat). Perkawinan sesama jenis dilarang keras dalam Islam karena jauh dari prinsip maslahat. Hal ini karena dapat mengancam eksistensi kemaslahatan manusia yang bersifat esensial, yakni tidak terjaganya keberlangsungan keturunan manusia (bif̨̌h al-nash). Karena dengan perkawinan sesama jenis akan meruntuhkan sistem keluarga dan masyarakat, sebab hubungan seksual sesama jenis tidak akan menghasilkan sebuah pola reproduksi yang sehat. Dikarenakan hubungan tersebut tidak akan mengakibatkan bertemunya sel sperma dan sel telur, sehingga tidak menghasilkan keturunan. Padahal secara kodrati Tuhan merancang hubungan antara seoranglaki-laki dan perempuan sebenarnya adalah agar tersebar keturunan untuk dapat memakmurkan bumi. ${ }^{34}$

Disamping itu, perkawinan sesama jenis kaum LGBT bertentangan dengan hif₹̧ al-nafs karena dapat mengancam jiwa manusia yang seharusnya dilindungi, sebab hubungan seksual sesama kaum LGBT dapat berisiko tertular penyakit yang membahayakan kelangsungan hidup seseorang seperti HIV AIDS. Selain penyakit AIDS ada pula penyakit akibat hubungan seksual yang tidak pada tempatnya, seperti sipilis. Menurut para ahli, penyakit ini menular dengan hubungan seksual, seperti zina, homoseks, dan lesbian. Kuman sipilis

33JasserAuda, Membumikan Hukum Islam Melalui Maqasid Syariah, Bandung: Mizan Media Utama, 2008, h. 34

${ }^{34}$ Sinyo, Anakku Bertanya Tentang LGBT, Jakarta: Elex Media Komputindo, 2017, h. 10 
berkembang biak melalui luka, yang menular dengan cepat. Penyakit ini sangat berbahaya, penderitanya dapat menjadi lumpuh karena lemahnya daya tahan tubuh, dan membawa kematian. ${ }^{35}$ Cerminan penafian penghormatan terhadap jiwa manusia ini sungguh bertentangan dengan konsepsi Islam yang sangat menghargai setiap jiwa manusia.

Hal lainnya adalah dalam perkawinan LGBT tidak dapat terpenuhinya kemaslahatan manusia berupa perlindungan akal (bif̌̌ $h$ al-'aqb) karena hubungan sesama jenis dapat berdampak buruk terhadap rusaknya saraf otak, melemahnya akal, dan menurunnya semangat kerja. Orang yang melakukan penyimpangan seksual dapat menghilangkan keseimbangan akal, kedunguan dan kesesatan pemikiran. Hal itu disebabkan karena sedikitnya getah endokrin dalam tubuh yang dihasilkan oleh kelenjar gondok dan kelenjar lain secara keseluruhan. Hal ini muncul akibat pengaruh dari penyimpangan seksual. Selain itu, tujuan perkawinan adalah untuk menjaga kehormatan diri (bif̌̌b al-irdl), sebagaimana tertuang dalam QS. Al-Nisa' ayat 24 dan QS. Al-Maidah ayat 5.

Berdasarkan kedua ayat tersebut perkawinan yang dilakukan sesama kaum LGBT berarti mengabaikan prinsip perlindungan kehormatan (bifž alirdl) yang berakibat pada rusaknya harkat dan martabat manusia (khususnya pelaku) baik di hadapan Tuhan maupun sesama manusia, karena perilaku homoseksual itu merupakan perbuatan keji yang masuk kategori dosa besar sebagaimana delik perzinahan. ${ }^{36}$

Dengan demikian, maka perkawinan sesama jenis kaum LGBT adalah mudarat karena dapat mengancam eksistensi kebutuhan esensial bagi kehidupan manusia, yaitu tidak terpeliharanya agama, jiwa, keturunan, akal, dan kehormatan. Dalam kaidah fikih, kemudharatan harus dihilangkan sedapat mungkin (al-dlararu yudfa'u bi qadri al-imkân). Maksudnya adalah jika sesuatu itu dianggap sedang atauakan bahkan memang menimbulkan kemudharatan, maka keberadaannya wajib dihilangkan. Kaidah lainnya yang relevan adalah kemudharatan harus dihilangkan (al-dlararuyuzâlu).

Melihat besarnya dampak yang ditimbulkan dari hubungan LGBT ketimbang manfaatnya, maka perkawinan sesama jenis dari kaum LGBT adalah dilarang. Sebagaimana kaidah fikih "Menghindarkan mafsadat didahulukan atas mendatangkan maslahat" (dar' al-mafâsidmuqaddam 'alajjalb al-mashâlih). Menurut Syathibi, ada tiga syarat suatu perbuatan itu dilarang: (a) perbuatan itu membawa kepada mafsadah secara mutlaq; (b) mafsadah dari perbuatan itu lebih kuat dari maslahahnya; (c) unsur mafsadah dalam perbuatan itu jelas-jelas lebih banyak

${ }^{35}$ Dikutip oleh Qomaruzzaman, Sanksi Pidana Pelaku LGBT dalam Perspektif FikihJinayah, Raheema, Jurnal Studi Gender dan Anak IAIN Pontianak, Vol. 3, No. 1, 2016, h. 94

${ }^{36}$ Rohmawati, Perkawinan Lesbian, Gay, Biseksual, dan Transgender (LGBT) Perspektif Hukum Islam, AHKAM, Jurnal Hukum Islam IAIN Tulungagung, Volume 4, Nomor 2, November 2016, h. 322 
dari maslahahnya. ${ }^{37}$ Keharaman perkawinan LGBT juga didasarkan pada kaidah ushûl fikih yang mengatakan: "Pada dasarnya hubungan seks adalah haram, sehingga ada dalil (sebab-sebab yang jelas dan yakin tanpa keraguan) yang menghalalkannya, yakni adanya akad nikah."

Berdasakan pertimbangan mafsadah di atas, maka perkawinan sesama jenis dari kaum LGBT dipandang sebagai tablil al-barâm (menghalalkan yang haram) yang dosanya lebih besar daripada melanggar yang haram itu sendiri. Menurut fuqaha', menahan ajakan hawa nafsu jauh lebih ringan daripada menanggung akibat buruk dari hubungan homoseksual.Dengan demikian, melegalkan perkawinan LGBT dipandang lebih berat dosanya karena menganggap halal atas perkara yang diharamkan. ${ }^{38}$

\section{Perspektif Fikih tentang Perkawinan LGBT}

Perkawinan merupakan sunnatullah yang terikat pada ketentuan hukum Islam. Dalam kodifikasi hukum Islam (fikih) tidak ditemukan ketentukan hukum yang secara khusus menjelaskan perkawinan sejenis. Hal ini karena perbuatan homoseksual adalah perbuatan yang dilarang, sehingga tidak mungkin dilegalkan dalam perkawinan yang sah. Sah atau tidaknya sebuah perkawinan ditentukan oleh terpenuhi atau tidaknya semua rukun dan syarat perkawinan. Para ulama' berbeda pandangan tentang penentuan rukun dan syarat perkawinan karena mereka berbeda dalam melihat fokus perkawinan itu sendiri. Namun perbedaan tersebut tidak bersifat substanisal. Di dalam berbagai literatur fikih, terutama mazhab Syafi'i, perkawinan itu dinyatakan sah jika memenuhi syarat-rukun perkawinan, yaitu: a) calon suami yang muslim; b) calon istri, meskipun Yahudi atau Nasrani; c) wali nikah dari calon istri; d) dua orang saksi yang adil; dan e) ijab dan qabul yang jelas.

Berdasarkan pada syarat-rukun perkawinan tersebut dapat dipahami bahwa perkawinan meniscayakan adanya pasangan calon mempelai dari jenis kelamin yang berbeda (laki-laki dan perempuan), tidak boleh lain daripada itu seperti sesama laki- laki atau sesama perempuan. Ketentuan hukum ini bersifat aklamatif antargenerasi yang berarti bernilai ijma' al-ummah (kesepakatan seluruh umat Islam). Dengan demikian, perkawinan sejenis yang dilakukan oleh kaum LGBT dinyatakan tidak sah dan haram karena menyimpang dari ijma' karena dilakukan sejenis. ${ }^{39}$

Selain dari aspek keabsahan perkawinan tersebut, larangan perkawinan LGBT dapat ditelusuri dari pendapat ulama' tentang keharaman perilaku homoseksual. Mengaitkan hukum perkawinan LGBT dengan larangan perilaku

\footnotetext{
${ }^{37}$ Al-Syatibi, al-Munâfaqat fi Ushûl al-Syarîah, h. 8

${ }^{38}$ Ahmad Zahro, Fikib Kontemporer, Menjawab 111 Masalah Aktual Hukum Islam di Zaman Kita, t.tp: PT QafMediaKreativa, 2016, h. 141

${ }^{39}$ Rohmawati, AHKAM, h. 318-319
} 
homoseksual sangatlah relevan, karena menurut jumhur ulama esensi dari sebuah pernikahan adalah li al-istimtấ' (bersenang-senang) atau menyalurkan kebutuhan biologis. Penyaluran kebutuhan biologis harus melalui institusi perkawinan yang sah berdasarkan syariat.

Berbeda dengan lesbian dan gay, ulama fikih memberikan perhatian terhadap perkawinan khuntsâ meskipun dalam porsi yang sedikit. Dalam banyak ketentuan fikih, terutama dalam peran sosial, khuntsâ diidentikkan sebagai "perempuan", namun tidak serta merta dapat dianggap sebagai perempuan yang bisa berpasangan dengan laki-laki. Hal ini sebagaimana dikisahkan Al-Malibari tentang waria yang dibakar hidup-hidup karena melakukan perkawinan:

"Dikisahkan bahwa Khalid bin Walid menulis surat kepada Abu Bakar perihal adanya seorang laki-laki yang menikah seperti nikahnya seorang perempuan. Kemudian persoalan itu dibahas Abu Bakar bersama Ali bin Abi Thalib dan para sahabat lainnya. Ali berpendapat bahwa orang tersebut harus dibakar dalam keadaan hidup- hidup. Para sahabat sepakat membakarnya. Lalu Khalid bin Walid membakar laki- laki tersebut dalam keadaan hidup-hidup." ${ }^{40}$

Al-Suyuthi dalam kitab al-Asybah wa al-Nazhâir mengemukakan bahwa pernikahan kbuntsâ hukumnya antara sah dan tidak sah. Menurutnya, ketika terjadi pernikahan dua orang khuntsâ kemudian jelas bahwa kedua-duanya adalah laki-laki, maka sebagian mengatakan sah dan sebagian lainnya mengatakan tidak sah. Al-Nawawi menganggap perkawinan tersebut sah karena meng-qiyaskannya dengan sahnya shalat yang tanpa disertai kemantapan niat. Namun ketika ada seorang laki- laki menikahi seorang khuntsâ kemudian menjadi jelas bahwa ternyata ia perempuan (atau sebaliknya, perempuan menikahi khuntsâ kemudian menjadi jelas bahwa ia laki-laki), maka dengan mengutip pendapat al-Rauyani yang disepakati ibn Rif 'ah,al-Suyuthi cenderung memilih berpendapat bahwa perkawinan tersebut tidak sah. ${ }^{41}$

Menurut al-Suyuthi, persoalan mengenai pernikahan khuntsâ lebih rumit daripada persoalan mengenai shalatnya khuntsâ. Sehingga harus mengutamakan unsur kehati-hatian dalam persoalan pernikahan kbuntsâ. Hal ini karena persoalan nikah tidak hanya berdampak bagi pasangan mempelai saja, sementara shalat dampaknya terbatas pada yang mengerjakan shalat. Jika khuntsâ didentifikasi sebagai laki-laki, maka hukum menikahnya harus dengan perempuan. Sebaliknya, jika kbuntsâ diidentifikasi sebagai perempuan, maka hukum menikahnya harus dengan laki-laki. ${ }^{42}$

Adapun mengenai pernikahan transgender/waria dengan kategori

${ }^{40}$ Zainuddin al-Malibari, Irsyâd al-Tbâd, Jakarta: Al-Ridha, t.th, h. 117

${ }^{41}$ Jalal al-Din al-Suyuthi, al-Asybahwa al-Naz̧hair, Surabaya: Al-Hidayah, 1965, h. 156-157

42Jalal al-Din al-Suyuthi, al-Asybahwa al-Naz̧hâir, hlm. 157-158 
mukhannats min ashl al-kbilqah (kodrati) yang lebih diterima dan tidak dilaknat, belum ditemukan ketentuan hukumnya secara pasti. Sehingga memungkinkan adanya formulasi hukum Islam yang mampu memberikan solusi atas kebuntuan hukum bagi perkawinan mukhannats yang bersifat kodrati tersebut. Hal ini berbeda dengan pernikahan transgender/waria dengan kategori mukhannats bi altakalluf (dibuat- buat), hukumnya jelas sama dengan lesbian dan gay, yakni tidak sah.

\section{Perspektif Kompilasi Hukum Islam tentang Perkawinan LGBT}

Di dalam KHI, tidak ada ketentuan secara khusus tentang perkawinan sejenis yang dilakukan oleh kaum LGBT. Tetapi dalam beberapa pasal KHI mengisyaratkan bahwa perkawinan itu hanya boleh dilakukan oleh pasangan suami istri dari jenis kelamin yang berbeda, yaitu laki-laki dan perempuan. Pasalpasal tersebut antara lain; Pasal 1 huruf a yang menjelaskan bahwa "Peminangan ialah kegiatan upaya ke arah terjadinya hubungan perjodohan antara seorang pria dengan seorang wanita". Selanjutnya Pasal 1 huruf dmenyebutkan"Mahar adalah pemberian dari calon mempelai pria kepada calon mempelai wanita, baik berbentuk barang, uang, atau jasa yang tidak bertentangan dengan hukum Islam".Pasal tersebut dipertegas lagi oleh Pasal 30 yang menyebutkan bahwa "calon mempelai pria wajib membayar mahar kepada calon mempelai wanita dengan jumlah, bentuk dan jenisnya disepakati oleh kedua belah pihak".

Selain pasal-pasal di atas, terdapat pasal lain dalam KHI yang juga menyebutkan pasangan perkawinan adalah berjenis kelaminlaki-laki dan perempuan, yaitu Pasal 14 yang berbunyi bahwa "untuk melaksanakan perkawinan harus ada calon suami, calon istri, wali nikah, dua orang saksi, dan ijab qabul". KemudianPasal 15 (1) menyebutkan bahwa "untuk kemaslahatan keluarga dan rumah tangga, perkawinan hanya boleh dilakukan calon mempelai yang telah mencapai umur yang ditetapkan dalam pasal 7 UU No.1 Tahun 2014 yakni calon suami sekurang-kurangnya berumur 19 tahun dan calon istri sekurang-kurangnya berumur 16 tahun".Yang dimaksud calon suami dalam kedua pasal tersebut adalah seorang laki-laki dan calon istri adalah ditujukan untuk perempuan.

SelanjutnyaPasal 16 (2)menyebutkan bahwa bentuk persetujuan calon mempelai wanita dapat berupa pernyataan tegas dan nyata dengan tulisan, lisan atau isyarat tapi dapat juga berupa diam dalam arti selama tidak ada penolakan yang tegas.Kemudian pasal 29 ayat (3) yang berbunyi "dalam hal calon mempelai wanita atau wali keberatan calon mempelai pria diwakili, maka akad nikah tidak oleh dilangsungkan.Kedua pasal tersebut secara tegas menyebutkan pasangan perkawinan terdiri dari laki-laki dan perempuan.

Pasal-pasal tersebut di atas secara tegas menjelaskan bahwa hubungan perkawinan adalah antara laki-laki dan perempuan.Sehingga dapat dipahami bahwa hukum Islam hanya membolehkan adanya perkawinan antara laki-laki 
dan perempuan.Jadi, dapat kiranya disimpulkan bahwa perkawinan sesama jenis tidak dapat dilegalkan karena tidak memenuhi syarat perkawinan berdasarkan hukum Islam di Indonesia.

\section{Perkawinan LGBT Perspektif Hukum Positif}

Dalam perspektif hukum, sebuah perbuatan seksual tidak dapat dipidana sepanjang tidak merugikan orang lain, sehingga tidak menimbulkan akibat hukum. Dalam hukum pidana Indonesia tidaklah mengenal tentang istilah LGBT,karena istilah ini dianggap sebagai istilah medis dan psikologi. Barulah dapat berakibat pidana atau timbul akibat hukum apabila telah terjadi kejahatan atau ada hubungan kausalitas antara penyimpangan seksual dengan kejahatan tersebut.

Dalam hukum pidana, suatu penyimpangan atau kejahatan yang dilakukan kaum homoseksual diatur dalam Buku 2 KUHP Bab XIV tentang Kejahatan Kesusilaan Pasal 292 berikut: "Orang dewasa yang melakukan perbuatan cabul dengan orang yang belum dewasa dari jenis kelamin yang sama, sedang diketahuinya atau patut harus disangkanya hal belum dewasa itu, diancam pidana penjara lima tahun".

Pasal tersebut menjelaskan bahwa yang diancam hukuman dalam pasal ini adalah orang dewasa yang melakukan perbuatan cabul dengan anak yang belum dewasa. Dalam hal ini dewasa yang dimaksudkan adalah telah berumur 21 tahun atau belum berumur 21 tahun akan tetapi sudah pernah kawin. Yang dimaksud jenis kelamin yang sama adalah bahwa antara pelaku dengan korban harus sesama jenis kelamin, yakni laki-laki dengan laki-laki atau perempuan dengan perempuan, dengan demikian dia bisa seorang gay atau seorang lesbi.

Pertimbangan Pasal 292 KUHP ini didasarkan atas kehendak pembentuk Undang-Undang untuk melindungi kepentingan orang yang belum dewasa, yang menurut keterangan dengan perbuatan homoseksual ini kesehatannya akan sangat terganggu, terutama jiwanya. ${ }^{43}$ Jika mengkaji KUHP Pasal 292 di atas, ada beberapa hal yang bisa dianalisis: (a) Hukum pidana memandang homoseksual sebatas perilaku seks yaitu perbuatan cabul. Artinya, ketika hubungan homoseksual itu dilakukan secara suka rela atau suka sama suka maka perbuatan tersebut tidak dapat ditindak pidana; (b) Mengancam sanksi pidana kepada orang dewasa yang melakukan hubungan seksual sesama jenis dengan orang yang belum dewasa. Artinya adalah bahwa pidana hanya dikenakan apabila si pelakunya adalah orang dewasa dan KUHP tidak menganggap orang yang belum dewasa sebagai si pelaku; (c) Obyeknya adalah orang sesama jenis yang belum dewasa. Artinya, jika obyeknya adalah orang yang sudah dewasa, maka tidakakan terkena sanksi pidana.Dengan demikian, perilaku

\footnotetext{
${ }^{43}$ WirjonoProdjodikoro, Tindak-tindak Pidana Tertentu di Indonesia, Bandung: PT. RefikaAditama, 2003, h.120
} 
menyimpang atau perbuatan cabul dengan orang lain yang sama jenis kelaminnya yang berumur di atas 18 tahun tidak dapat dijerat oleh hukum pidana.

Konsep perkawinan di Indonesiasebagaimana termaktub dalam pasal 1 ayat (2)Undang-undang No. 1 Tahun 1974 adalah: "perkawinan adalah ikatan lahir batin antara seorang pria dan seorang wanita sebagai suami istri dengan tujuan membentuk keluarga atau rumah tangga yang bahagia dan kekal berdasarkan Ketuhanan Yang Maha Esa.”

Pasal tersebut secara tegas menjelaskan bahwa perilaku seksual hanya diwadahi dalam perkawinan yang merupakan "ikatan lahir batin" antara seorang pria dan seorang wanita. Dengan demikian tidak ada celah bagi warga negara Indonesia untuk melakukan perkawinan sesama jenis. Pencantuman berdasarkan Ketuhanan Yang Maha Esa mengindikasikan bahwa perkawinan mempunyai hubungan yang erat sekali dengan agama, sehingga perkawinan bukan saja mempunyai unsur lahir/jasmani, tetapi juga memiliki unsur batin/rohani. ${ }^{44}$ Kemudian pasal tersebutdisebutkan: "Yang dimaksud dengan perkawinan adalah ikatan lahir batin antara seorang pria dan seorang wanita sebagai suami istri berdasarkan ketentuan Peraturan Perundang- undangan."

Perlunya perkawinan yang dicatatkan selain untuk bukti otentik dan perlindungan terhadap hak seseorang yang berada dalam perkawinan, berhubungan erat dengankesejahteraan sosial, yakni kondisi dimana kebutuhan material, spiritual, dan sosial warga negara dapat terpenuhi agar dapat hidup layak dan mampu mengembangkan diri, sehingga dapat melaksanakan fungsi sosialnya. Maka dapat dipahami bahwa jika perkawinan sesama jenis oleh kaum LGBT dilakukan oleh warga negara Indonesia, maka perkawinannya tidak dapat diakui (tidak memiliki kekuatan hukum) karena bertentangan dengan aturan perundang-undangan dan tidak dapat dilaporkan ke instansi terkait sebagai suami isteri sehingga jaminan kesejahteraan sosial dari negara tidak bisa diperuntukkan bagi kaum LGBT yang melakukan perkawinan untuk membentuk sebuah keluarga.

Indonesia merupakan negara yang mengakui dan menjunjung tinggi hak asasi manusia dan kebebasan dasar manusia sebagai hak yang secara kodrati melekat pada dan tidak terpisahkan dari manusia yang harus dilindungi, dihormati dan ditegakkan demi peningkatan martabat kemanusiaan, kesejahteraan, kebahagiaan, dan keadilan. Pengakuan, jaminan, perlindungan dan perlakuan hukum yang adil serta mendapat kepastian hukum dan perlakuan yang samadidepan hukum diberikan kepada warga negara tanpa diskriminasi.

Meskipun setiap warga negara mempunyai hak asasi manusia dan

\footnotetext{
${ }^{44}$ Moh. Idris Ramulyo, Hukum Perkawinan Islam: Suatu Analisis dari Undang-Undang No. 1 Tahun 1974 dan Kompilasi Hukum Islam, Jakarta: Bumi Aksara, 1996, h. 2
} 
kebebasan dasar manusia seperti hak untuk hidup, hak berkeluarga dan melanjutkan keturunan, hak untuk mengembangkan diri, hak untuk kebebasan pribadi, hak atas rasa aman, hak atas kesejahteraan, hak berpartisipasi dalam pemerintah,tetapi setiap warga negara memiliki kewajiban dasar berupa wajib patuh pada peraturan perundang- undangan, hukum tak tertulis dan hukum internasional mengenai hak asasi manusia, ${ }^{45}$ dan setiap warga negara wajib menghormati hak asasi manusia orang lain, etika,moraldan tata tertib kehidupan bermasyarakat, berbangsa dan bernegara.

Namun demikian, hal yang perlu diperhatikan adalah bahwa dalam perkawinan sesama jenis yang dilakukan kaum LGBT dengan mengatasnamakan hak dan kebebasan memilih untuk menentukan sendiri perkawinannya tidak diatur dalam undang-undang tentang hak asasi manusia. Akan tetapi hak yang diatur dan dilindungi adalah hak untuk membentuk keluarga dan melanjutkan keturunan melalui perkawinan yang sah.Dimanaperkawinan sah yang dimaksud adalah ketikadilangsungkan atas kehendak calon suami dan calon istri, yang bersangkutan, sesuai dengan ketentuan perundang-undangan. ${ }^{46} \mathrm{Hal}$ ini sebagaimana yang tercantum dalam Undang-Undang No. 39 Tahun 1999 tentang Hak Asasi Manusia bagian kedua tentang Hak Berkeluarga dan Melanjutkan Keturunan pasal 10 bahwa:

"Setiap orang berhak untuk membentuk suatu keluarga dan melanjutkan keturunan melalui perkawinan yang sah.Perkawinan yang sah hanya dapat berlangsung atas kehendak bebas calon suami dan calon istri yang bersangkutan, sesuai dengan peraturan perundang-undangan".

Pasal tersebut secara tegas menjelaskan bahwa hak berkeluarga dan melanjutkan keturunan hanya dapat dilakukan melalui perkawinan yang sahsesuai dengan ketentuan perundang-undangan yang berlaku, yang secara khusus diatur dalam Undang-undang No. 1 Tahun 1974 tentang Perkawinan. Lahirnya Undang- Undang ini menunjukkan bahwa Negara memiliki konsep sekaligus kepentingan atau intervensi kekuasaan dalam mengatur hubungan perkawinan dan keluarga di masyarakat.

Kebebasan hak asasi di Indonesia diberikan dengan pembatasan, yakni pertama, tidak boleh melanggar hak asasi orang lain; kedua, kebebasan dibatasi dengan nilai- nilai moral; ketiga, kebebasan dibatasi oleh nilai-nilai agama. Sehingga pernikahan sesama jenis yang dilakukan kaum LGBT bukan merupakan hak yang harus dilindungi akan tetapi patut untuk ditolak tegas karena negara Indonesia memiliki standar hukum negara. Standar hukum ini termaktub dalam Undang-Undang Dasar 1945 dan Pancasila.

\footnotetext{
${ }^{45}$ Pasal 67 Undang-undang No. 39 tahun 1999 tentang Hak Asasi Manusia

${ }^{46}$ Pasal 10 Undang-undang No. 39 tahun 1999 tentang Hak Asasi Manusia
} 
Dari pemahaman di atas jelas bahwa perkawinan sesama jenis yang dilakukan oleh kaum LGBT meskipun dengan dalih hak asasi manusia bukanlah merupakan tindakan keputusan yang manusiawi. Dengan demikian tidak tepat jika menuntut untuk dimanusiakan sebagaimana kodratnya manusia sebabia tidak menjadikan dirinya manusia yang sesuai kodratnya, sehingga mendapatkan pengakuan dan hak yang sama dari manusia yang lain. Perkawinan sesama jenis oleh kaum homoseksual jika dilegalkan juga tidak dapat dikatakan adil dan beradab, karena ini merupakan keputusan yang sewenang-wenang jika menafikan keberadaban budaya Indonesia, bertentangan dengan ideologi bangsa serta tata perundang-undangan di Indonesiadilangsungkan atas kehendak calon suami dan calon istri, yang bersangkutan, sesuai dengan ketentuan perundangundangan. ${ }^{47} \mathrm{Hal}$ ini sebagaimana yang tercantum dalam Undang-Undang No. 39 Tahun 1999 tentang Hak Asasi Manusia bagian kedua tentang Hak Berkeluarga dan Melanjutkan Keturunan pasal 10 bahwa: "Setiap orang berhak untuk membentuk suatu keluarga dan melanjutkan keturunan melalui perkawinan yang sah. Perkawinan yang sah hanya dapat berlangsung atas kehendak bebas calon suami dan calon istri yang bersangkutan, sesuai dengan peraturan perundangundangan".

Pasal tersebut secara tegas menjelaskan bahwa hak berkeluarga dan melanjutkan keturunan hanya dapat dilakukan melalui perkawinan yang sahsesuai dengan ketentuan perundang-undangan yang berlaku, yang secara khusus diatur dalam Undang-undang No. 1 Tahun 1974 tentang Perkawinan. Lahirnya Undang- Undang ini menunjukkan bahwa Negara memiliki konsep sekaligus kepentingan atau intervensi kekuasaan dalam mengatur hubungan perkawinan dan keluarga di masyarakat.

Kebebasan hak asasi di Indonesia diberikan dengan pembatasan, yakni pertama, tidak boleh melanggar hak asasi orang lain; kedua, kebebasan dibatasi dengan nilai- nilai moral; ketiga, kebebasan dibatasi oleh nilai-nilai agama. Sehingga pernikahan sesama jenis yang dilakukan kaum LGBT bukan merupakan hak yang harus dilindungi akan tetapi patut untuk ditolak tegas karena negara Indonesia memiliki standar hukum negara. Standar hukum ini termaktub dalam Undang-Undang Dasar 1945 dan Pancasila.

Dari pemahaman di atas jelas bahwa perkawinan sesama jenis yang dilakukan oleh kaum LGBT meskipun dengan dalih hak asasi manusia bukanlah merupakan tindakan keputusan yang manusiawi. Dengan demikian tidak tepat jika menuntut untuk dimanusiakan sebagaimana kodratnya manusia sebab ia tidak menjadikan dirinya manusiayang sesuai kodratnya, sehingga mendapatkan pengakuan dan hak yang sama dari manusia yang lain. Perkawinan sesama jenis oleh kaum homoseksual jika dilegalkan juga tidak dapat dikatakan adil dan beradab, karena ini merupakan keputusan yang sewenang-wenang jika 
menafikan keberadaban budaya Indonesia, bertentangan dengan ideologi bangsa serta tata perundang-undangan di Indonesia.

\section{Persamaan Hukum Perkawinan LGBT dalam Hukum Islam dan Hukum Positif}

Berdasarkan paparan di atas dapat dipahami bahwa perkawinan LGBT yang dilakukan sesama jenis baik dalam perspektif hukum Islam maupun hukum positif adalah dilarang. Ketentuan larangan pernikahan LGBTtersebut adalah berdasarkan jenis kelamin.Jikadilakukan sesama jenis maka tidak diperbolehkan. Adapun bagi kaum biseksual, yang mengalami orientasi seksual kepada dua jenis kelamin sekaligus,ketentuan hukumnya ada dua, jika ialebih memilih untuk menikah dengan pasangan yang lain jenis dengannya maka perkawinannya sah, tetapi jika dilakukan sesama jenis maka tidak sah perkawinannya. Demikian halnya dengan kaum transgender yang mengalami penggantian alat kelamin berdasarkan pertimbangan medis dan psikologis, telah diakui secara sah perubahan statusnya oleh Pengadilan Negeri, serta dibenarkan oleh agama Islam, maka hukum perkawinan yang berlaku adalah harus dilakukandengan pasangan yang memiliki jenis kelamin yang berbeda setelah dilakukannya penggantian alat kelamin tersebut.

Secara singkat, persamaan hukum perkawinan LGBT antara hukum Islam dan hukum positif dapat dilihat dalam tabel berikut:

\begin{tabular}{|c|c|c|c|c|c|}
\hline \multirow{2}{*}{$\begin{array}{l}\text { Ragam } \\
\text { Seksualitas }\end{array}$} & \multirow{2}{*}{$\begin{array}{l}\text { ModelAlat } \\
\text { Kelamin }\end{array}$} & \multicolumn{2}{|c|}{ Ketentuan Hukum } & \multicolumn{2}{|l|}{ Dasar Hukum } \\
\hline & & $\begin{array}{l}\text { Hukum } \\
\text { Islam }\end{array}$ & $\begin{array}{l}\text { Hukum } \\
\text { Positif }\end{array}$ & Hukum Islam & Hukum Positif \\
\hline Lesbian & $\begin{array}{l}\text { Sama alat } \\
\text { Kelamin }\end{array}$ & Dilarang & Dilarang & \multirow{6}{*}{$\begin{array}{l}\text { Alquran ,hadis } \\
\text { Maqashid al- } \\
\text { Syari'ah Fikih } \\
\text { K o m p i l a s i } \\
\text { H u k u m Islam } \\
\text { (pasal } 1,30,14 \text {, } \\
15,16,29 \text { ) }\end{array}$} & \multirow{6}{*}{$\begin{array}{l}\text { UU } \\
\text { Perkawinan } \\
\text { pasal } 1 \text { ayat (2), } \\
\text { pasal } 2 \text { ayat (1) } \\
\text { dan (2); UU } \\
\text { Admin istrasi- } \\
\text { Kependudukan } \\
\text { pasal } 34 \text { ayat } \\
\text { (1); UU HAM } \\
\text { pasal } 10\end{array}$} \\
\hline Gay & $\begin{array}{l}\text { Sama alat } \\
\text { Kelamin }\end{array}$ & Dilarang & Dilarang & & \\
\hline \multirow[t]{2}{*}{ Biseksual } & $\begin{array}{l}\text { Sama alat } \\
\text { Kelamin }\end{array}$ & Dilarang & Dilarang & & \\
\hline & $\begin{array}{l}\text { Beda alat } \\
\text { Kelamin }\end{array}$ & $\begin{array}{l}\text { Diperbole } \\
\text { hkan }\end{array}$ & $\begin{array}{l}\text { Diperbol } \\
\text { ehkan }\end{array}$ & & \\
\hline \multirow[t]{2}{*}{ Transgender } & $\begin{array}{l}\text { Sama alat } \\
\text { Kelamin }\end{array}$ & Dilarang & Dilarang & & \\
\hline & $\begin{array}{l}\text { M e r u b a h } \\
\text { alat kelamin }\end{array}$ & $\begin{array}{l}\text { Diperbole } \\
\text { hkan }\end{array}$ & $\begin{array}{l}\text { Diperbol } \\
\text { ehkan }\end{array}$ & & \\
\hline
\end{tabular}




\section{Kesimpulan}

Perkawinan yang dilakukan sesama jenis oleh kaum LGBT dilarang oleh Islam karena menyalahi kodrat dan bertentangan teks keagamaan serta maqâshid al-syari'ah, karena perkawinan sesama jenis dapat mengancam eksistensi kebutuhan esensial bagi kehidupan manusia, yaitu tidak terpeliharanya agama, jiwa, keturunan, akal, dan kehormatan.Apabila perkawinan LGBT itu dilakukan maka dianggap tidak sah dan dipandang sebagai tahlîlal-haram (menghalalkan yang haram) yang dosanya lebih besar daripada melanggar yang haram itu sendiri. Dalam perspektif hukum positif Indonesia, negara hanya membolehkan perkawinan yang dilakukan antara laki-laki dan perempuan, dan pelaksanaannya harus sesuai dengan agamanya masing-masing. Sementara semua agama di Indonesia, termasuk Islam, tidak membolehkan adanya perkawinan sejenis. Jika dilakukan perkawinan sesama jenis oleh kaum LGBT, maka perkawinannya bertentangan dengan peraturan perundang-undangan Indonesia, dan tidak dapat dilaporkan atau dicatatkan ke instansi terkait sebagai suami isteri sehingga jaminan kesejahteraan sosial dari negara tidak bisa diperuntukkan bagi kaum LGBT yang melakukan perkawinan.

\section{Daftar Pustaka}

Aini, Inayatul, Kisah Homoseksual Kaum Nabi Luth dalam Alquran Menurut Penafsiran Musdah Mulia dan Husei Mubammad, Skripsi Fakultas Ushuluddin dan Pemikiran Islam UIN Yogyakarta

Al-'Asqalani, Ahmad ibn Ali ibn Hajar, Fath al-Bari, Jilid IX Beirut: al-Risalah al'Alamiyyah, 2013

Al-Ba'li, Muhammad binAbi al-Fath, Al-Mutthali' 'alaAlfarh al-Muqni', Juddah: Maktabah al-Sawadi, 2003

Al-Haitsami, al-Hafidz Nur ad-Din Ali binAbiBakr, Majma’ DrawaidwaManba'alFawaid, Beirut: Dar al-Fikr, 1992, Vol. VI

Ali, Zainuddin, Metode Penelitian Hukum, Jakarta: Sinar Grafika, 2013

Al-Malibari, Zainuddin, Irsyad al-Ibad, Jakarta: Al-Ridha, t.th

Al-Nawawi, Abu ZakariyaYahya bin Syaraf, TabrirAlfaz̧ al-Tanbih, Damaskus: Dar al-Qalam, 1988

SyarhShabih Muslim, Jilid XIII, t.tp: Dar al-Khair, 1998

Al-Qurtubi, Abu al-Hasan Ali bin Khalaf bin Abdil Malik bin Baththal al-Bakri, Syarbu Sabih al-Bukhari li Ibni al-Baththal, Riyad: Maktabah al-Rusyd, 2003, Vol. IX

Al-Suyuthi, Jalal al-Din, al-Asybahwa al-Nazhair, Surabaya: Al-Hidayah, 1965 
Al-Suyûthi, al-Durru al-Mantsûrfì al-Tafüir al-Ma'tsûr, Beirut: Dar al-Kutub alIlmiyah, t.th

Al-Syatibi, al-Munvafaqat fi Ushul al-Syariah, Beirut: Dar al-Ma'rifah, 1996

Al-Zuhaili, Wabbah, al-Fikih al-Islami waAdillatuh, Beirut: Dar al-Fikr, 1985

Auda, Jasser, Membumikan Hukum Islam Melalui Maqasid Syariah, Bandung: MizanMedia Utama, 2008

Babbie, Earl, The Practice of Social Research, Wadsworth Publishing Co. Calofornia, 1986

Bukhari, Imam, Shabih Bukhari, Kitab al-Libas, hadis nomor 5886, diakses dari www.hadithportal.com

Hadi, Sutrisno, Metodologi Research, Cet. Ke-2, Yogyakarta: Andi Offset, 1989

Husaini, Adian, Seputar Paham Kesetaraan Gender, Depok: Adabi Press, 2012

IbnKatsir, Ismail, Tafsir IbnKatsir, Jilid III, Pinang:SulaimanShur'iy, t.th

Miskari, Wacana Melegalkan LGBT di Indonesia (Studi Analisis LGBT dalam Perspektif HAMdan Pancasila), dalam Jurnal Raheema, 2017

Mulia, Musdah, Seksualitas Lesbian, Jurnal Perempuan, 58

Nakhe’i, Imam, LGBT Perspektif Islam, Jurnal Lisan Al-Hal, Volume 4, No. 2, Desember 2012 Nawawi, Syekh M., QutulHabibilGharib, TausyihalaFathilQaribilMujib, Cetakan I, Beirut:DarulFikr, 1996

Prodjodikoro,Wirjono,Tindak-tindak Pidana Tertentu di Indonesia, Bandung: PT. Refika Aditama,2003

Qomaruzzaman, Sanksi Pidana Pelaku LGBT dalam Perspektif Fikihjinayah,

Raheema, Jurnal Studi Gender dan Anak, Vol.3, No.1, 2016

Ramulyo, Moh. Idris, Hukum Perkawinan Islam: Suatu Analisis dari Undang-Undang No. 1 Tabun 1974 dan Kompilasi Hukum Islam, Jakarta: Bumi Aksara, 1996

Rofiq, Ahmad, Hukum Perdata Islam di Indonesia, Edisi Revisi, Jakarta: Raja Grafindo Persada,2013

Rohmawati, Perkawinan Lesbian, Gay, Biseksual, dan Transgender (LGBT) Perspektif

Hukum Islam, AHKAM, Jurnal Hukum Islam LAIN Tulungagung, Volume 4, Nomor 2, November 2016

Sabiq, Sayyid, Fikih al-Sunnah, juz VI, Beirut: Dar al-Fikr, 1980

Sarwono, Sarlito Wirawan, Psikologi Remaja, Jakarta: Raja Grafindo Persada, 2006

Shihab, M. Quraish, Membumikan Alquran: Fungsidan Peran Wabyudalam Kebidupan 
Masyarakat, Bandung: Mizan, 2000

Pengantin Alquran, Kalung Permata Buat Anak-Anakeku, Jakarta: Lentera Hati, 2010

Sinyo, Anakku Bertanya Tentang LGBT, Jakarta: Elex Media Komputindo, 2017

Sulaiman, Abu Dawud bin Al-Asy-ats, SunanAbiDawnd, Cet. 1, Dimasyq: Dar alRisalah al-Alamiyah, 2009

Syarifuddin, Amir, UshulFikih, Jilid II, Jakarta: Logos, 1997

Syawqi, Abdul Haq, Kawin Sejenis dalam Pandangan Musdah Mulia, Skripsi, UIN YogyakartaTahun 2009

Wizarah al-AwfaqwaSyum al-Islami, Mausu'ah al-Fikihiyah al-Kuwaitiyah, t.tp: Dar as-Safwah, $1427 \mathrm{H}$, Vol. XXIV

Zahro, Ahmad, Fikih Kontemporer, Menjawab 111 Masalah Aktual Hukum Islam di Zaman Kita, t.tp:PTQaf Media Kreativa, 2016 